ELORE (ISSN 1456-3010), vol. 20 - 1/2013.

Julkaisija: Suomen Kansantietouden Tutkijain Seura ry.

[http://www.elore.fi/arkisto/1_13/heimo.pdf]

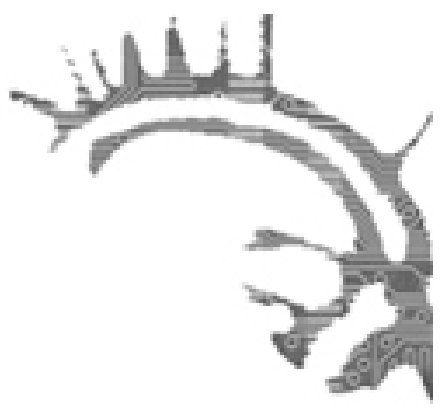

\title{
KIRJA-ARVIO
}

\section{KENTTÄÄ ETSIMÄSSÄ}

HIRVI, LAURA \& SNELLMAN, HANNA (ed.) 2012: Where is the Field? The Experience of Migration Viewed through the Prism of Ethnographic Fieldwork. Studia Fennica Ethnologica 14. Helsinki: SKS. 221 sivua.

\section{Anne Heimo}

Jokaiselle kenttätöitä tehneelle on kertynyt omaan henkilökohtaiseen repertuaariinsa joukko tarinoita kentällä tapahtuneista hauskoista tai jännittävistä sattumuksista ja tilanteista. Näitä kertomuksia on mukava vaihtaa kanssatutkijoiden kanssa seminaarien väliajoilla ja konferenssien illanistujaisissa. Yhteiset kokemukset luovat yhteenkuuluvaisuutta ja herättävät kunnioitusta niiden parissa, joilla vastaavia kokemuksia ei (vielä) ole. Joskus näistä kerrotaan myös opiskelijoille ja aloitteleville tutkijoille, mutta artikkelikokoelman Where is the Field? The Experience of Migration Viewed through the Prism of Ethnographic Fieldwork -kirjan toimittajien Laura Hirven ja Hanna Snellmanin mukaan ei riittävän usein. Kenttätyö- eli etnografisia menetelmiä kyllä opetetaan monilla aloilla, mutta pääosa kenttätyöhön liittyvästä tiedosta on sanatonta, hiljaista tietoa, joka omaksutaan luento- ja seminaarisalien ulkopuolella.

Where is the Field? -kirjassa pohditaan kentän merkitystä ja sijaintia tänä päivänä. Tutkijan kenttä sijaitsee yhä harvemmin "malinowskilaisittain" jossain kaukana, missä tutkija vierailee yksin pitkähkön ajanjakson kerrallaan, ja josta palattuaan hän kirjoittaa tutkimuksensa. Nykyään tutkija saattaa jojoilla eli vierailla kentällä moneen otteeseen ja kenttä voi sijaita samanaikaisesti eri puolilla, tai tutkijan ei tarvitse matkustaa minnekään, vaan kenttä tulee luokse työhuoneelle ja kotiin, ja on läsnä silloinkin, kun tutkija ei ole työssä. Miten näissä tapauksissa tutkija määrittelee kenttänsä sijainnin, sen rajat ja kenttätyönsä keston? 
Anne Heimo: Kenttää etsimässä

\section{YHDEKSÄN TARINAA KENTÄLTÄ}

Artikkelikokoelman kirjoittajiin kuuluu tutkijanuran eri vaiheissa olevia tutkijoita eri aloilta, etnologeja, antropologeja ja uskontotieteilijöitä eri puolilta maailmaa. Etnografisten menetelmien käytön lisäksi heitä yhdistää se, että he tutkivat siirtolaisuutta. Siirtolaisuudella (migration) kirjassa tarkoitetaan ensisijaisesti työperäistä maahanmuuttoa. Useassa kirjan artikkelissa nämä työn perässä muuttaneet ovat korkeakoulutettuja, asiantuntijoita ja luovien alojen edustajia, niin kutsuttuja expateja, ekspatriaatteja. Ekspatriaatit asuvat ulkomailla toistaiseksi eivätkä pysyvästi ja saattavat muuttaa uusien haasteiden perässä maasta toiseen. He eivät välttämättä myöskään muodosta uudessa kotimaassaan tiivistä yhteisöä, vaikka saattavatkin kuulua yhteiseen Facebook-ryhmään. Ekspatriaatteja on luonteva kuvata elämäntavaltaan mobiileiksi, mutta on hyvä pitää mielessä, että heihin kuuluu kasvava joukko enemmän tai vähemmän pakolla kotimaastaan siirtotyöläisiksi tai pakolaisiksi joutuneita, jotka joutuvat usein olemaan vuosia matkalla uuteen kotimaahansa.

Kirja on jaettu kolmeen teemaan. Ensimmäisen teeman neljä artikkelia käsittelevät "vaikeasti tavoitettavien tavoittamista". Osan artikkelit tarkastelevat erilaisia mobiileja, hajanaisia ja vaikeasti paikannettavia yhteisöjä sekä tutkijan keinoja paikallistaa kohteensa ja luoda yhteys siihen. Kirjan toisessa osassa tarkastellaan "yhteisöjen luomista". Siinä missä kenttä oli ennen yhtä kuin tietty yhteisö, joutuu tutkija nyt pohtimaan mikä hänen tutkittaviaan yhdistää ja miettimään, millä nimellä kutsua joukkoa, joka ei välttämättä tunne toisiaan. Kolmannen osan teemana on "Kerrottu ja ei-kerrottu". Osan artikkelit käsittelevät kertomatta jättämisen merkitystä sekä kentän luomista kertomalla. Kirjan yhdeksän artikkelia esittelevät keinoja, joilla tutkijat voivat ottaa haltuun yhteiskunnan muutokset. Kirjan loppuun sijoitettu hakemisto olisi helpottanut eri teemojen seuraamista artikkeleissa.

\section{NojATUOLIETNOGRAFiAN PALUU}

Internet on kulttuurisesti omaksuttu (Suominen 2009, 8-9) ja muuttunut osaksi arkipäiväämme viimeistään 2000-luvun kuluessa. Kun vielä 1990-luvulla tutkijat suhtautuivat online- ja offline-elämään toisistaan erillisinä ja poikkeavina, nähdään ne nykyään toistensa jatkumoina. Ihmiset tekevät samoja asioita netissä kuin sen ulkopuolella: hoitavat ihmissuhteitaan, asioitaan ja työtehtäviään, vaikuttavat, harrastavat ja leikkivät. Viime vuosina on ilmestynyt koko joukko internet-etnografisia tutkimuksia ja jonkin verran menetelmäoppaita, mutta vain harvoja etnografisten menetelmiin erikoistuneilla tieteenaloilla, kuten antropologiassa, etnologiassa ja folkloristiikassa. Vielä harvemmin saa lukea siitä, miten yksittäinen tutkija soveltaa menetelmiä käytännössä ja millaisin seurauksin. Tästä syystä Laura Hirven ja Saara Koikkalaisen artikkelit ovat erityisen tarpeellisia ja kiinnostavia luettavia.

Christine Hine $(2000,65)$ määrittelee internet-etnografian tutkimukseksi, joka tapahtuu verkossa, kohdistuu verkkoon tai tehdään verkon välityksellä (ethnography in, of 
and through the virtual). Tuoreessa digitaalista mediaurheilun seuraamista käsittelevässä väitöskirjassaan Riikka Turtiainen (2012) lähestyy nettiä tutkimuksen lähteenä, kohteena ja välineenä. Mutta nettiä voi lähestyä myös tilana, ihmisten kohtaamispaikkana ja tutkijan kenttänä, kuten arvioitavassa kirjassa tehdään. Internet-etnografiaan liittyy monia haasteita. Online- ja offline-etnografian käytön tarve riippuu siitä, tutkiiko yhteisöjä online vai online-yhteisöjä (Kozinets 2010, 65). Jos yhteisö toimii sekä verkossa että sen ulkopuolella on suositeltavaa, että myös tutkija toimii molemmissa ympäristöissä kokonaiskuvan saamiseksi, kuten Daniel Miller ja Don Slater (2000) oivallisesti osoittavat trinidadilaisten internetin käyttöä koskevassa digitaalisen antropologian klassikossaan.

Sekä Laura Hirven että Saara Koikkalaisen tutkimuksessa pääasiallinen syy internetin käyttöön oli tarkasteltavan yhteisön tavoittaminen. Koska etnologi Laura Hirven tarkoitus oli tutkia sikhejä offline, hänelle internet oli ensisijaisesti väline löytää tutkittavansa ja pitää heihin yhteyttä. Tällä hetkellä sikhejä asuu Suomessa noin 600, pääosa pääkaupunkiseudulla. Kalifornian Yuba Cityssa sikhejä on asunut jo sadan vuoden ajan, ja he ovat varsin näkyvä osa paikallista kaupunkikuvaa. Suomessa asuvien sikhien tavoittamisen Hirvi aloitti tiedustelemalla yhteyksiä Etnisten suhteiden ja kansainvälisen muuttoliikkeen tutkimuksen seuran postituslistan välityksellä. Hän saikin ensimmäiset haastateltavansa listalaisten kautta. Lisäksi hän haki haastateltavia Facebookin välityksellä hakemalla ihmisiä, joiden sukunimi kuulosti sikhiläiseltä. Löytämilleen ihmisille hän lähetti yhteydenottopyynnön Facebookin sähköpostin välityksellä. Näistä osa vastasi hänelle, mutta vain kaksi päätyi haastateltavaksi.

Sosiologi Saara Koikkalainen päätyi tutkimaan suomalaisia expateja pelkästään internetissä, koska ympäri Eurooppaa asuvien tutkittavien tavoittaminen muulla tavoin olisi ollut liian vaikeaa. Tutkittaville verkkoympäristö oli muutenkin luonteva kohtauspaikka. Suomalaiset expatit pitävät yhteyttä verkkosivuilla, keskustelupalstoilla ja Facebookissa. Koikkalaisen päätöstä vahvisti Ulf Hannerzin (2003) näkemys nyky-yhteiskunnassa tapahtuneissa muutoksissa, kuten työtavoissa, ja niiden vaikutuksista etnografisiin menetelmiin: Mitä järkeä on havainnoida tietokoneella päivät pitkät työskenteleviä? Koska expatit eivät keskustelleet työnhausta juurikaan verkossa ja hän koki osallistuvan havainnoinnin verkossa tutkimuseettisesti haastavaksi, Koikkalainen päätti toteuttaa tutkimuksensa survey-kyselynä. Koikkalaisen Työntekijänä Euroopassa-online-kysely tavoitti kaiken kaikkiaan yli 500 suomalaista 12 eri Euroopan maasta. Näistä 18 hän haastatteli Skypen välityksellä. Skype osoittautui edulliseksi ja käteväksi välineeksi, jonka käyttö sopi hyvin kiireellisille haastateltaville. Ainoa puute oli se, että vaikka kumpikin osapuoli näki toisensa, haastattelija ei päässyt tutustumaan haastateltavan asuin- tai työympäristöön eikä tapaamaan hänen perhettään.

Tutkimuseettiset kysymykset ovat oleellinen osa kaikkea tutkimusta, mutta internetetnografiassa ne ovat korostuneesti läsnä. Internetissä ero yksityisen ja julkisen, avoimen ja suljetun välillä on häilyvä. Nykyään osallistuvaa havainnointia verkossa ilman, että ilmoittaa läsnäolostaan, ei pidetä tutkimuseettisesti suotavana, vaikka sivusto tai foorumi olisi julkinen. Ihmiset eivät välttämättä miellä niitä julkisiksi eivätkä välttämättä halua olla tutkimuksen kohteita tietämättään. Ei ole yksiselitteistä yhtä oikeaa tapaa käyttää netin eri palveluja ja sovelluksia tutkimuseettisesti oikein, vaan tutkijan on joka kerta mietittävä ratkaisujaan ja niiden seurauksia. Hirven ensimmäinen yritys löytää tutkitta- 
via Facebookin avulla tapahtui aikana, jolloin kyseinen verkkoyhteisöpalvelu vasta teki tuloaan Suomessa. Vaikka Facebook mahdollistaa ihmisten haun, Hirvi kokee, että tänä päivänä hän mieluummin ilmoittaisi tutkimuksestaan ja hakisi tutkittavia esimerkiksi Helsingin gurdwaran kotisivujen kautta kuin ottaisi yhteyttä suoraan yksityisiin ihmisiin, kuten aikanaan teki.

Kummankin tutkijan kenttätyökokemukset puhuvat uudenlaisen kentän määrittelemisen tarpeesta. Saara Koikkalaisen kenttä sijaitsi siellä missä hän ja hänen tietokoneensa. Laura Hirvi koki Suomessa kenttänsä kovin hajanaiseksi, mutta taas Yuba Cityssa ollessaan se sijaitsi kaikkialla. Silloin, kun hän ei ollut fyysisesti läsnä, Hirvi saattoi silti kokea olevansa kentällä tietoteknologian avulla. Tietokoneen ja kännykän ansiosta hän pysyi yhteydessä tutkittaviinsa, mutta samalla ne vaikeuttivat hänen poistumisensa kentältä. Hirvi päätyykin näkemykseen, että kenttää ei voi määritellä etukäteen, vaan tutkija muodostaa sen tutkimusprosessinsa aikana tekemiensä valintojen ja ratkaisujen perusteella. Osa valinnoista on puhtaasti käytännöllisiä. Hirvi huomasi, että hänen oli usein helpompi havainnoida siinä Yuba Cityn neljästä sikhitemppelissä, gurdwarassa, jonne hän pääsi pyörällä, eikä automatkan päässä sijaitsevissa. Tutkittavat tekevät myös itse valintoja päättämällä kutsuvatko tutkijan kotiinsa, vastaavatko yhteydenottoon tai suostuvatko haastateltavaksi. Näkemys kentän rakentumisesta tutkimusprosessin päätteeksi on lohdullinen, koska tutkijan ei enää tarvitse kokea epäonnistuneensa, kun hänen suunnitelmansa eivät sujukaan odotetusti.

\section{PÄIVITETTYä SIIRTOLAISUUSTUTKIMUSTA}

Siirtolaisuus eikä siirtolaisuustutkimus ole enää ennallaan. Artikkelikokoelma päivittää kuvaa nykypäivän siirtolaisuudesta ja sitä koskevasta tutkimuksesta. Antropologiassa mobiliteettitutkimus (mobility studies) kuuluu jo kiinteästi siirtolaisuustutkimukseen (migration studies), mutta (suomalaisessa) folkloristiikassa ja etnologiassa ei. Pääosa folkloristisesta ja etnologisesta siirtolaisuutta koskevasta tutkimuksesta noudattaa perinteistä asetelmaa tietyn yhteisön tutkimisesta tietyssä paikassa. Sama pätee uuden siirtolaisuuden tutkimukseen käytettyihin metodeihin. Myös ne on päivitettävä, jotta niillä voidaan tavoittaa nykypäivän siirtolaiset.

Kirjan teemana on siirtolaisuus, mutta sitä voi suositella kaikille etnografisista menetelmistä kiinnostuneille lukijoille. Kirjoittajat reflektoivat kentällä kohtaamiaan esteitä, haasteita ja mahdollisuuksia ja niistä selviytymistä. Kirjan tarkoitus on tarjota ratkaisumalleja ja hyviä käytäntöjä kentälle ensimmäistä kertaa suuntaaville kuin jo kokeneille kenttätyöntekijöille olivat he jo matkalla kentälle tai vasta laatimassa tutkimussuunnitelmaansa. Vaikka keskityin arviossani vain internet-etnografiaa käsitteleviin artikkeleihin näiden uutuuden ja harvinaisuuden vuoksi, kirja tarjoaa kokonaisuudessaan kiinnostavan lukukokemuksen. Ensinnäkin se haastaa kyseenalaistamaan "vanhoja", mutta edelleen osittain tutkijoiden keskuudessa eläviä käsityksiä etnografisesta kentistä ja kenttätyömenetelmistä - vai miksi muutoin koemme huonommuutta, jos oma kenttämme ei sijaitse kaukana vaikeakulkuisen matkan päässä? Toiseksi se tuo helpotusta, kun asiat 
eivät menekään odotetusti ja tutkimussuunnitelman mukaisesti. Jojoilu ja metodiset cocktailit kuuluvatkin asiaan.

Kaikkia etnografisen tutkimusprosessin vaiheita ei kirjassa käsitellä. Kirjan toimittajat esittävät, että jatkossa olisi tarpeen paneutua aineiston analyysiin vaiheisiin. Miten tukijat analysoivat kaiken kentällä kokoamansa materiaalin tutkimukseksi. Millaisia vaiheita analyysiin sisältyy? Kenttätöihin liittyvien tutkimuseettisten kysymysten tarkastelu ja niistä kirjoittaminen on tänä päivänä itsestään selvä osa tutkimusprosessia. Mutta mitä tapahtuu tutkijan kokoamalle aineistolle tutkimuksen valmistuttua? Onko aineiston paikka arkistossa vai pitääkö se hävittää? Uskon, että en ole ainoa, joka jo odottaa jatko-osaa!

\section{KirjallisuUs}

HANNERZ, ULF 2003: Being there... and there... and there! Reflections on multi-sited ethnography. - Ethnography 4(2).

HINE, CHRISTINE 2000: Virtual Ethnography. London: Sage.

KOZINETS, ROBERT V. 2010: Netnography. Doing Ethnographic Research Online. Los Angeles etc.: Sage.

MILLER, DANIEL \& SLATER, DON 2000: The Internet: An Ethnographic Approach. Oxford: Berg Publishers.

SUOMINEN, JAAKKO 2009: Johdannoksi: netin kulttuurihistoriaa. - Saarikoski, Petri, Suominen, Jaakko, Turtiainen, Riikka \& Östman, Sari (toim.), Funetista Facebookiin. Internetin kulttuurihistoria. Helsinki: Gaudeamus.

TURTIAINEN, RIIKKA 2012: Nopeammin, laajemmalle, monipuolisemmin. Digitalisoituminen mediaurheilun seuraamisen muutoksessa. Kulttuurituotannon ja maisemantutkimuksen julkaisuja 37. Turku: Turun yliopisto. [online] <https://www. doria.fi/bitstream/handle/10024/85069/diss2012Turtiainen.pdf ?sequence $=1>$ [3.4.2013.]

Suomen Akatemian tutkijatohtori Anne Heimo Turun yliopistosta tutkii australiansuomalaisten muistoja siirtolaisuudesta online ja offline. 